\title{
COMPARATIVE ANALYSIS OF SOME HEAVY METALS LEVELS IN LEAVES, PEELS AND TUBERS OF CASSAVA PLANTED ALONG EAST- WEST ROAD RIVERS STATE
}

\author{
Ogah, Isaac Eguarkhide ${ }^{* 1} \bowtie(D)$, Ekpete A. Ozioma ${ }^{2}$ \\ Department of Chemistry, Ignatius Ajuru University of Education, Rumuolumeni, Port Harcourt, Nigreria. \\ ${ }^{2}$ Department of Chemistry, Ignatius Ajuru University of Education, Rumuolumeni, Port Harcourt, Nigreria.
}

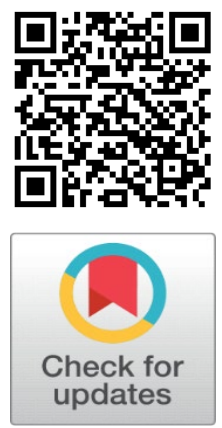

Received 17 July 2021

Accepted 20 August 2021

Published 31 August 2021

\section{CorrespondingAuthor}

Ogah, Isaac Eguarkhide,

write2isaacogah@yahoo.com

DOI

10.29121/granthaalayah.v9.i8.2021. 4012

Funding: This research received no specific grant from any funding agency in the public, commercial, or not-for-profit sectors.

Copyright: (C) 2021 The Author(s). This is an open access article distributed under the terms of the Creative Commons Attribution License, which permits unrestricted use, distribution, and reproduction in any medium, provided the original author and source are credited.

\section{ABSTRACT}

Introduction: Pollution of the environment by heavy metals has caused serious environmental problems, which threatens the existence of various ecological system, agriculture and human health. This study assessed the comparative analysis of some heavy metal's levels in leaves, peels and tubers of cassava planted along East-West Road Rivers State.

Materials/Methods: Cassava leaves and tubers samples were collected from farmlands along East-West Road (SX, SY and SZ communities, in Emohua, Tai, and Ahoada West LGA respectively), River's state, Nigeria. The samples were monitored for heavy metals levels to assess the impact of automobiles on cassava peels, leaves and tubers using Solar Thermo Elementary Atomic Absorption Spectrometer, ModelSG 71906. Metals studied were Lead (Pb), Nickel (Ni), Chromium (Cr), Cadmium (Cd), and Arsenic (As).

Results: The mean concentration of Ni present in leaf was $2.81 \pm 0.104 \mathrm{mg} / \mathrm{kg}$, tubers recorded $2.23 \pm 0.073 \mathrm{mg} / \mathrm{kg}$ and peels $3.20 \pm 0.06 \mathrm{mg} / \mathrm{kg}$. The highest concentration $(4.064 \pm 0.035 \mathrm{mg} / \mathrm{kg})$ of $\mathrm{Ni}$ was observed in peels while the least concentration $(1.80 \pm 1.023 \mathrm{mg} / \mathrm{kg})$ was recorded in the tubers. The mean values of $\mathrm{Pb}$ in leaves, tubers and peels were $2.22 \pm 1.023 \mathrm{mg} / \mathrm{kg}, 1.80 \pm 1.023 \mathrm{mg} / \mathrm{kg}$ and $2.64 \pm 0.32$, highest concentration was recorded in tubers. Arsenic values were $0.16 \pm 0.020 \mathrm{mg} / \mathrm{kg}>$ $0.51 \pm 0.021 \mathrm{mg} / \mathrm{kg}>0.38 \pm 0.203 \mathrm{mg} / \mathrm{kg}$ in peels, tubers and leaves respectively. The values of as were above WHO safe limit of $0.1 \mathrm{mg} / \mathrm{kg}$. Also, the mean values of cadmium in leaves, tubers and peels were $0.054 \pm 0.570 \mathrm{mg} / \mathrm{kg}, 0.046 \pm 0.057 \mathrm{mg} / \mathrm{kg}$ and $0.16 \pm 0.609$ $\mathrm{mg} / \mathrm{kg}$ respectively. The highest concentration $(0.138 \pm 0.109 \mathrm{mg} / \mathrm{kg})$ was in the tubers. Finally, chromium was found to be present in all the cassava samples (leaves, peels and tubers). The mean concentration of chromium (Cr) was $3.58 \pm 0.023 \mathrm{mg} / \mathrm{kg}, 2.76 \pm 0.005$ $\mathrm{mg} / \mathrm{kg}$ and $3.83 \pm 0.203 \mathrm{mg} / \mathrm{kg}$ in leaves, tubers and peels respectively.

Conclusion: From the findings, heavy metals were found in the samples and thus, crops should be cultivated far away from major roads.

Keywords: Comparative, Metals, Peels, Tubers, Cassava

\section{INTRODUCTION}

Pollution of the environment by heavy metals has caused serious environmental problems, which threatens the existence of various ecological system, agriculture and human health Wang et al. (2007). Massive loads of pollutants are being introduced into the water, air and land on a daily basis as a result of this development in technology and its related activities Dibofori-Orji, and Edori, (2015). This has led tremendously to global environmental pollution.

How to cite this article (APA): Ogah, I. E. and Ekpete, O. A. (2021). Comparative Analysis of Some Heavy Metals Levels in Leaves, Peels and Tubers of Cassava Planted Along East-West Road Rivers State. International Journal of Research - GRANTHAALAYAH, 9(8),

1-13. doi: 10.29121/granthaalayah.v9.i8.2021.4012 
Heavy metals are naturally present in soil in relatively low concentrations usually in milligram or nanogram level Nussey (1998). However, recently, the occurrence of heavy metals in excess of natural quantities has emerged as a result of domestic and industrial effluents, urban storm-water run-offs, smoke from in-use vehicles and leaching of metals from solid waste dump Biney et al.(1994), Idris et al. (2014). The composition of road side sediments shows that it is made up of materials from different sources such as run-off water from surrounding soils and slopes, dry and wet atmospheric deposition, road paint degradation, inputs from the wear of sidewalks, wear from road surface, vehicle wear, vehicle fluid and particulate emissions. Lately, studies have shown that the level of lead in plants and soil have increased by a remarkably large quantity as a result of pollution from automobiles, particularly from usage of leaded petrol and combustion from exhaust Ano et al. (2007), Ondeet al. 2007, Osakwe (2009). The discharge of these contaminants into water bodies, seas and land is having adverse effect on the crops that are planted along the major highways Ekpete and Festus (2013).

Nigerian soil particularly those along the highways is being bio accumulated by heavy metals giving rise to serious contagious disease to crops, animals and human beings.

Cassava (Manihot esculenta) plays a vital role in terms of income generation, employment creation and food security for families in Rivers State, mainly those in the rural environments where these cassavas are abundantly cultivated. Cassava is an important food, sold fresh or processed in such a way that it can easily be stored in different forms such as garri, fufu, flour and starch for domestic use and commercial purposes. Cassava roots and leaves can also be fed to livestock.

One of the major pathways by which contaminant and heavy metals in soils enter the food chain is through soil to plant transfer Sparg et al. (2004). Food crops such as cereal, tuber crops and vegetables cultivated in crude oil impacted soil take up toxic metal from the soil Harmanescu et al. (2011). Basically, most heavy metals are not biodegradable, have long biological half-lives and have the potential for accumulation in different body organs leading to unwanted side effects Mbong, et al. (2014). Apau et al. (2014) posited that accumulation of heavy metals in crop plants is often of great concern due to its potential for food contamination through the soil root interface (Apau et al. 2014).

Urbanization, fast and unorganized industrialization has contributed to the increased level of metals in the urban area in the developing nations. These heavy metals which are non-biodegradable and are pollutant are deposited on the soil surfaces are being absorbed into the tissues of plants. Plant takes up these heavy metals by absorbing them Amoah (2008).

Smokes from automobiles often contains high concentration level of heavy metals, these elements at high concentration exceeding the physiological demand of plants could discharge toxic in the plants and also could enter the food chain, get biomagnified and pose a potential threat to human's health. Thus, this research was designed to investigate heavy metals accumulation in cassava leaves (Manihot esculenta) cultivated along east-west road in River's state, Nigeria. 


\section{MATERIALS AND METHODS}

\subsection{DESCRIPTION OF STUDY AREA}

The study area East-West Road is a major road that connects different Local Government Areas in Rivers State. The specific areas of study include Ndele, Nonwa, and Odhiolugboji in Emohua, Tai, and Ahoada West L.G.A respectively, Rivers State, Nigeria.

Ndele is a town located in Emohua L.G.A of Rivers State. Ndele is located approximately between latitude 04058 '05"-040 58'08" $\mathrm{N}$ and longitude 0060 44'

44 '-0060 45'05"E. It is bounded to the north by Elele alimini and then to the south by Rumuekpe.

Ahoada West is a city in Orashi Region of Rivers State, Nigeria, located northwest of Port Harcourt. It is located between Latitude: $5^{\circ} 4^{\prime} 58.1412^{\prime \prime} \mathrm{N}$ and Longitude: 6 39' 30.4812" E.

Nonwa is a town located in Tai L.G.A of Rivers state. It is located between Latitude $4.71670 \mathrm{~N}$ and Longitude 7.30000E.

\subsection{SAMPLE COLLECTION AND TREATMENT}

Fresh cassava leaves, cassava tubers and peels were randomly collected from six spots (25 meters apart) from three different farmlands cultivated along eastwest road, in Rivers State (farm SX, SY, and SZ). The samples were identified and packed into polyethylene bags. Each of the cassava samples were pooled together to obtain good representation and then divided into three portions for composite replicate analyses (Alinnor, 2004). The samples were washed with tap water to remove any surface deposits (dust and any other particles that may act as contaminants), and rinsed with distilled water. They were sliced using knife to aid drying at room temperature. The samples were air dried for four days in the laboratory to remove moisture and oven-dried at $60^{\circ} \mathrm{C}$ to a constant weight. The dried samples were pulverized to fine powder using a mortar and pestle. Each of the processed powder was subjected to acid digestion (Alinnor, 2004) and the concentrations of the heavy metals $\mathrm{Cd}, \mathrm{Cr}, \mathrm{Pb}, \mathrm{As}$ and $\mathrm{Ni}$ in the solutions were determined using Solar Thermo Elementary Atomic Absorption Spectrometer, ModelSG 71906.

\subsection{ACID DIGESTION OF THE SAMPLES}

A measured weight ( $2 \mathrm{~g}$ ) each of ground samples (leaves, peels and tubers) was put into separate beakers, digested with $12 \mathrm{ml}$ of aqua regia $\mathrm{HNO} / \mathrm{HCl}$ (1:3) on a hot plate at $70^{\circ} \mathrm{C}$ until the brown fumes disappeared. Heating was continued until the brown fumes turned to white. $20 \mathrm{ml}$ of distilled water was added and heated until a colourless solution was obtained. The solution was allowed to cool and after cooling, the digested samples were filtered using Whatman No1 filter paper. The filtrates were made up to $100 \mathrm{mls}$ mark in volumetric flasks with distilled water (Alinnor, 2004). The concentrations of the heavy metals (Cd, Cr, As, Ni and Pb) in the cassava samples were determined using Solar Thermo Elementary Atomic Absorption Spectrometer, ModelSG 71906. 


\section{RESULTS}

Table 1 Concentration of $\mathrm{Nikel}(\mathrm{Ni}) \mathrm{mg} / \mathrm{kg}$ in cassava leaves, cassava peels and cassava tubers sourced from different farmlands cultivated along east-west road.

\begin{tabular}{llll}
\hline Cassava samples & SX & SY & SZ \\
\hline Cassava Leaves & $2.110 \pm 0.880$ & $3.916 \pm 0.903$ & $2.417 \pm 0.892$ \\
\hline Cassava tubers & $1.532 \pm 0.091$ & $2.107 \pm 0.099$ & $2.607 \pm 0.076$ \\
\hline Cassava Peels & $2.472 \pm 0.072$ & $4.064 \pm 0.035$ & $3.077 \pm 1.231$ \\
\hline WHO safe limit & 67.00 & & \\
\hline
\end{tabular}

Data are presented as mean $\pm \mathrm{SD},<0.001=$ below detection limit, $\mathrm{SX}=$ Samples from Ndele, SY= Samples from Nonwa, SZ = Samples from Odhiolugboji

\subsection{NICKEL (NI)}

From the research, nickel was found to be present in all the cassava samples (leaves, peels and tubers) that were analyzed. The estimated concentration of nickel (Ni) present in leaves ranged from $3.916 \pm 0.903 \mathrm{mg} / \mathrm{kg}>2.417 \pm 0.892 \mathrm{mg} / \mathrm{kg}>$ $2.110 \pm 0.880 \mathrm{mg} / \mathrm{kg}$ in SY, SZ, and SX respectively, with samples from SY having the highest concentration while SX had the least concentration. In tubers, SZ $(2.607 \pm 0.076 \mathrm{mg} / \mathrm{kg})$ had the highest concentration followed by SY $(2.107 \pm 0.099$ $\mathrm{mg} / \mathrm{kg})$ and SX $(1.532 \pm 0.09 \mathrm{mg} / \mathrm{kg})$. Also, SY, SZ and SX had values of $4.064 \pm 0.035$ $\mathrm{mg} / \mathrm{kg}, \quad 3.077 \pm 1.231 \mathrm{mg} / \mathrm{kg}$ and $2.472 \pm 0.072 \mathrm{mg} / \mathrm{kg}$ respectively. The concentrations of nickel (Ni) in the samples were below the maximum permissible concentration of $67 \mathrm{mg} / \mathrm{kg}$ set by WHO. Analysis of variance (one way ANOVA) findings among the three communities showed statistically significant difference $(p>0.05)$.

The mean value of nickel obtained in this study is however slightly higher than the work of Matthews - Amune and Kakulu $2013(0.06 \pm 0.005 \mathrm{mg} / \mathrm{kg})$ MathewsAmune and Kakulu (2012), Ubwa et al., 2013 (0.1031 mg/kg) Ubwa et al. (2013), but lower than the work of Oguntimehin and Ipinmoroti $2007(25.01 \mathrm{mg} / \mathrm{kg})$ Oguntimehin and Ipinmoroti (2007), Ogundiran and Osibanjo (2009) (24.4+10.1 $\mathrm{mg} / \mathrm{kg}$ ) Ogundiran and Osibanjo, (2009), Nwachukwu et al. (2013) (25.12mg/kg) Nwachukwu et al. (2013), Pam et al. (2013)(18.4mg/kg) Pam et al. (2013) and that of Ajiwe et al., 2018 (45.25 mg/kg and $20.25 \mathrm{mg} / \mathrm{kg}$ in tubers and leaves respectively) Ajiwe et al. (2018). Nickel was not detected by Akaniwor et al. (2005). Similar observation has been reported Ano et al. (2007), Osakwe (2009), Nabulo et al. 2006.

Though this study did not reveal any risk of acute toxicity, the slight increase in the concentration of $\mathrm{Ni}$ in the cassava plants may represents a risk in the future.

Table 2 Concentration of Lead $(\mathrm{Pb}) \mathrm{mg} / \mathrm{kg}$ in cassava leaves, cassava peels and cassava tubers sourced from different farmlands cultivated along east-west road.

\begin{tabular}{llll}
\hline Cassava samples & SX & SY & SZ \\
Cassava Leaves & $1.406 \pm 0.971$ & $3.372 \pm 1.059$ & $1.869 \pm 1.029$ \\
\hline
\end{tabular}




\begin{tabular}{llll} 
Cassava tubers & $0.633 \pm 0.102$ & $2.548 \pm 0.084$ & $2.671 \pm 0.121$ \\
Cassava Peels & $1.764 \pm 0.064$ & $3.749 \pm 0.051$ & $2.415 \pm 1.065$ \\
WHO safe limit & 0.30 & & \\
\hline
\end{tabular}

Data are presented as mean $\pm \mathrm{SD},<0.001=$ below detection limit, $\mathrm{SX}=$ Samples from Ndele, $\mathrm{SY}=$ Samples from Nonwa, SZ = Samples from Odhiolugboji

\subsection{LEAD (PB)}

This study revealed that lead $(\mathrm{Pb})$ was detected in the cassava samples from the three farmlands.

The concentration of lead in cassava leaves varies from one community to another as shown in Table 2, the highest concentration of lead in leaves was observed in SY $(3.372 \pm 1.059 \mathrm{mg} / \mathrm{kg})$ followed by SZ $(1.869 \pm 1.029 \mathrm{mg} / \mathrm{kg})$ and SX had the least value $(1.406 \pm 0.971 \mathrm{mg} / \mathrm{kg})$. Concentration of lead $(\mathrm{Pb})$ was also observed in the cassava tubers as follows; $2.671 \pm 0.121 \mathrm{mg} / \mathrm{kg}, 2.548 \pm 0.084 \mathrm{mg} / \mathrm{kg}$ and $0.633 \pm 0.102 \mathrm{mg} / \mathrm{kg}$ for SZ, SY and SX respectively with SZ $(2.671 \pm 0.121 \mathrm{mg} / \mathrm{kg})$ having the highest concentration while SX $(0.633 \pm 0.102 \mathrm{mg} / \mathrm{kg})$ had the least. Concentration of $\mathrm{Pb}$ in cassava peels ranged from $3.749 \pm 0.051 \mathrm{mg} / \mathrm{kg}>$ $2.415 \pm 1.065 \mathrm{mg} / \mathrm{kg}>1.764 \pm 0.064 \mathrm{mg} / \mathrm{kg}$ in SY, SZ and SX respectively. Analysis of variance (one way ANOVA) findings among the three communities showed no statistically significant difference $(\mathrm{p}>0.05)$.

This research work is in consonant with Udiba et al., 2019 (3.75 mg/kg, 2.59 $\mathrm{mg} / \mathrm{kg}$ and $0.43 \mathrm{mg} / \mathrm{kg}$ of lead in cassava peels, cassava tubers and cassava leave respectively) Udiba et al. (2019). The detection of $\mathrm{Pb}$ in various cassava samples (leaves, peels and tubers) may be attributed to the pollution from automobiles due to the proximity of the farmlands to a highway. Other likely sources of $\mathrm{Pb}$ are pollutants in irrigation water or farm soil on which the cassava was grown Qui et al. (2000). The concentration of $\mathrm{Pb}$ in the cassava is enough to cause toxicity as they are above WHO recommended permissible limit of $0.3 \mathrm{mg} / \mathrm{kg}$. The concentrations of lead in the cassava tubers recorded in the study were also higher than the available reported human toxicity levels of $1.00 \mathrm{mgPb} /$ day Abah et al. (2013).

Consumption of cassava from these communities thus poses significant risk of lead toxicity. The results obtained in this research work were higher than the work of Nwocha et al., 2011(1.93mg/kg) Nkwocha et al. (2011), Abah et al., 2013 $(0.840 \pm 0.230 \mathrm{mg} / \mathrm{kg}, 0.850 \pm 0.270 \mathrm{mg} / \mathrm{kg}$ and $0.870 \pm 0.250 \mathrm{mg} / \mathrm{kg})$ Abah et al. (2013), Osabohien et al. 2013 (0.012 mg/kg to $0.018 \mathrm{mg} / \mathrm{kg}$ ) [28], and Ogbolu et al., $2019(0.60-0.90 \mathrm{mg} / \mathrm{kg})$ Ogbolu et al. (2019), and lower than the work of Okoronkwo et al., 2005 (76.6 $\pm 19.94 \mathrm{mg} / \mathrm{kg})$ Okoronkwo et al. (2005).

However, chronic poisoning may not be ruled out since cassava peels are feed directly to livestock. The metal is thus introduced into the food chain through livestock. After absorption and distribution in the blood, $\mathrm{Pb}$ is initially distributed to soft tissues throughout the body. Eventually the bones accumulate the toxic metal over a much longer period Idakwoji (2016). As it is the custom to consume the whole animal when slaughtered, the consumption of edible tissues of food animals fed with cassava peels from the area over time might also cause high accumulation of lead. In Nigeria and many other countries of the world, meat and milk from cattle, goats and sheep are some of the most common sources of animal protein Ogabiela, et al. (2011). Plants readily bio-accumulate large quantity of Lead through their roots 
without much changes in their total yield and appearances Park et al. (2011), Oti and Nwabue (2013).

Research on the field have also shown that Lead accumulation could be anthropogenic, can also be very chronic when occurred above permissible limits, causes body ailments and easily leads to the weariness of the body tooth and bones Onyedika and Nwosu (2008), Ezeh and Chukwu (2011), Oti and Nwabue (2013).

Lead is a non-essential heavy metal. Lead causes oxidative stress and contributes to the pathogenesis of lead poisoning by disrupting the delicate antioxidant balance of the mammalian cells. High level accumulation of $\mathrm{Pb}$ in body causes anemia, colic, headache, brain damage, and central nervous system disorder Rehman et al. (2013). Consumption of $\mathrm{Pb}$ in edible plants poses a health risk to consumers. Lead is the most common of the heavy metals, accounting for $13 \mathrm{mg} / \mathrm{kg}$ of the earth's crust. Lead has no known biological function Wepener et al. (2001). The absorption of $\mathrm{Pb}$ is influenced by food intake with higher rates of absorption. Lead is a classical chronic or cumulative poison. In humans, $\mathrm{Pb}$ is known to cause a lot effects in the body system depending on the level and duration of exposure Idakwoji (2016). Due to the rapid rate of absorption in children, they are often more vulnerable to the effects of lead than adults Idakwoji (2016).

Table 3 Concentration of Arsenic (As) $\mathrm{mg} / \mathrm{kg}$ in cassava leaves, cassava peels and cassava tubers sourced from different farmlands cultivated along east-west road.

\begin{tabular}{llll}
\hline Cassava samples & SX & SY & SZ \\
\hline Cassava Leaves & $0.024 \pm 0.961$ & $0.849 \pm 0.781$ & $0.246 \pm 0.917$ \\
\hline Cassava tubers & $<0.001$ & $1.384 \pm 0.089$ & $0.160 \pm 0.075$ \\
\hline Cassava Peels & $0.142 \pm 0.012$ & $1.528 \pm 0.172$ & $0.308 \pm 0.987$ \\
\hline WHO safe limit & 0.1 & & \\
\hline
\end{tabular}

Data are presented as mean $\pm \mathrm{SD},<0.001=$ below detection limit, $\mathrm{SX}=$ Samples from Ndele, $\mathrm{SY}=$ Samples from Nonwa, $\mathrm{SZ}=$ Samples from Odhiolugboji

\subsection{ARSENIC (AS)}

From Table 3, the levels of arsenic in leaves were $0.024 \pm 0.961 \mathrm{mg} / \mathrm{kg}$, $0.849 \pm 0.781 \mathrm{mg} / \mathrm{kg}$ and $0.246 \pm 0.917 \mathrm{mg} / \mathrm{kg}$ in SX, SY and SZ respectively with SY $(0.849 \pm 0.781 \mathrm{mg} / \mathrm{kg})$ had the highest concentration. The results shows that arsenic was not detected in cassava tubers from SX $(<0.001)$ as it was below detection limit but present in $S Y(1.384 \pm 0.089 \mathrm{mg} / \mathrm{kg})$ and $S Z(0.160 \pm 0.075 \mathrm{mg} / \mathrm{kg})$. Also, the results obtained in cassava peels were $0.142 \pm 0.012 \mathrm{mg} / \mathrm{kg}, 1.528 \pm 0.172 \mathrm{mg} / \mathrm{kg}$ and $0.308 \pm 0.987 \mathrm{mg} / \mathrm{kg}$ in SX, SY and SZ respectively with SY having the highest concentration $(1.528 \pm 0.172 \mathrm{mg} / \mathrm{kg})$ while SX had the least concentration $(0.142 \pm 0.012 \mathrm{mg} / \mathrm{kg})$. It was observed from the result that the concentration of arsenic was above FAO/WHO permissible level of $0.1 \mathrm{mg} / \mathrm{kg}$ except in cassava tubers from SX. Analysis of variance (one way ANOVA) findings among the three communities showed no statistically significant difference ( $p>0.05)$.

High level of arsenic can cause death Galadima and Garba (2012). It was also reported that arsenic exceeding permissible limit $(0.1 \mathrm{mg} / \mathrm{kg})$ in food stuff could cause in the short term (nausea, vomiting, diarrhea, cough and headache) long term 
(cardiovascular diseases, diabetes and vascular diseases) human health effects Galadima and Garba (2012). The values obtained correspond with that of Essumang 2015 (0.017 mg/kg and $0.01 \mathrm{mg} / \mathrm{kg}$ ) Essumang (2015), Makanjuola 2016 $(0.32 \mathrm{mg} / \mathrm{kg}$ and $0.36 \mathrm{mg} / \mathrm{kg})$ Makanjuola (2006) and Ogbolu et al $2019(0.24$ $\mathrm{mg} / \mathrm{kg}$ ) Ogbolu et al. (2019). Consumption of cassava from these communities thus poses significant risk of arsenic toxicity as they were above FAO/WHO permissible level of $0.1 \mathrm{mg} / \mathrm{kg}$. High level of arsenic can cause death Col et al. (1999).

\begin{tabular}{|c|c|c|c|}
\hline Cassava samples & SX & SY & SZ \\
\hline Cassava Leaves & $0.029 \pm 0.570$ & $0.098 \pm 1.057$ & $0.038 \pm 0.609$ \\
\hline Cassava tubers & $<0.001$ & $0.138 \pm 0.109$ & $<0.001$ \\
\hline Cassava Peels & $0.0138 \pm 0.002$ & $0.435 \pm 0.076$ & $0.021 \pm 1.089$ \\
\hline WHO safe limit & 3.0 & & \\
\hline
\end{tabular}

Data are presented as mean $\pm \mathrm{SD},<0.001=$ below detection limit, $\mathrm{SX}=$ Samples from Ndele, SY= Samples from Nonwa, SZ = Samples from Odhiolugboji

\subsection{CADMIUM (CD)}

From Table 4, Cadmium concentrations in leaves were $0.029 \pm 0.570 \mathrm{mg} / \mathrm{kg}$, $0.098 \pm 1.057 \mathrm{mg} / \mathrm{kg}$ and $0.038 \pm 0.609 \mathrm{mg} / \mathrm{kg}$ in SX, SY and SZ respectively. In tubers, cadmium was not detected in SX and SZ as they were below detection limit; however, cadmium was only detected in SY $(0.138 \pm 0.109 \mathrm{mg} / \mathrm{kg})$. The result also showed that $0.0138 \pm 0.002 \mathrm{mg} / \mathrm{kg}, 0.435 \pm 0.076 \mathrm{mg} / \mathrm{kg}$ and $0.021 \pm 1.089 \mathrm{mg} / \mathrm{kg}$ were found in peels from SX, SY and SZ respectively. The mean concentration of cadmium in leaves $(0.055 \pm 0.745 \mathrm{mg} / \mathrm{kg})$, tubers $(0.138 \pm 0.109 \mathrm{mg} / \mathrm{kg})$ and peels $(0.157 \pm 0.389 \mathrm{mg} / \mathrm{kg})$ in the various samples and were below W.H.O permissible limit of $3.0 \mathrm{mg} / \mathrm{kg}$. Analysis of variance (one way ANOVA) findings among the three communities showed no statistically significant difference $(p>0.05)$.

The mean concentrations of cadmium in the various cassava peels, leaves and tubers were within the range of the values recorded by Dioborfori-Orji and Edori 2015 (0.04 $0.00 \mathrm{mg} / \mathrm{kg}$ ) Dibofori-Orji and Edori (2015), Essumang 2015 (0.002 $\mathrm{mg} / \mathrm{kg}$ ) Essumang (2015), Enemugwem et al., 2016 (0.18 mg/kg), Idakwoji 2016 $(0.02 \pm 0.01 \mathrm{mg} / \mathrm{kg})$ Idakwoji, 2016, and lower than $2.6 \mathrm{mg} / \mathrm{kg}$ reported by Mbong et al., 2014 (2.6mg/kg) Mbong et al. (2014).

Although the values recorded in this research were below W.H.O safe limit of $3.0 \mathrm{mg} / \mathrm{kg}$ in the long term, toxicity might however, arise from chronic accumulation of $\mathrm{Cd}$ if these plants are continuously consumed. The kidneys and liver store about 50 to $85 \%$ of $\mathrm{Cd}$ in the body with 30 to $60 \%$ being stored in the kidneys Anyakora et al. (2011). Cd has no known biological functions in the body but it interferes with some essential function of $\mathrm{Zn}$, thereby inhibiting enzyme reactions and nutrient utilization. It catalyzes oxidation reactions, generating free-radical tissue damage WHO (World Health Organisation). (1996). 


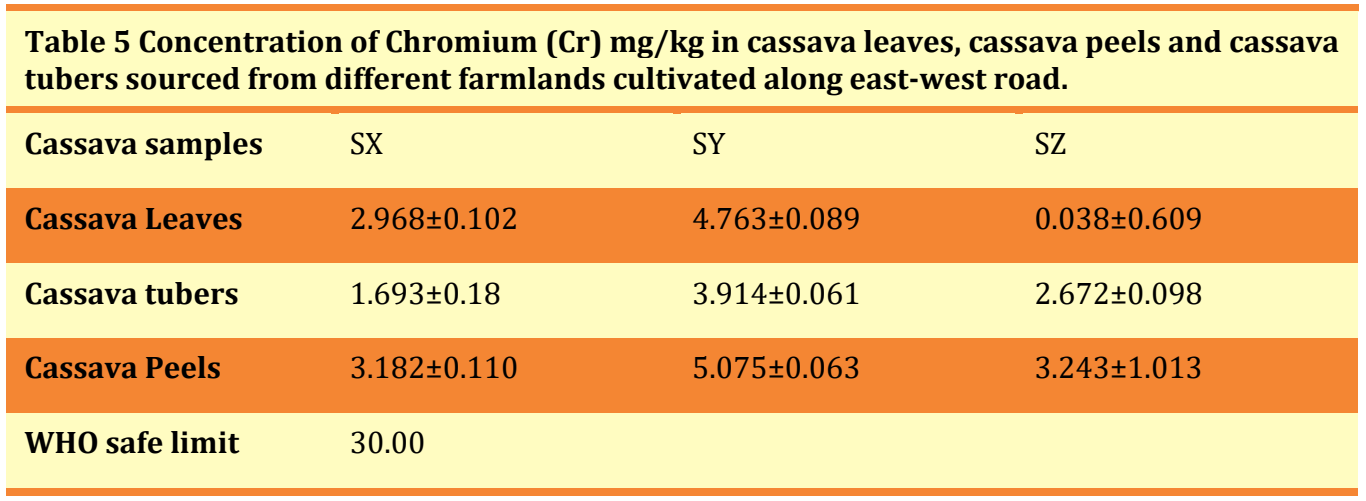

Data are presented as mean $\pm \mathrm{SD},<0.001$ = below detection limit, SX= Samples from Ndele, SY= Samples from Nonwa, SZ = Samples from Odhiolugboji

\subsection{CHROMIUM (CR)}

From the results in Table 5, chromium was found to be present in all the cassava samples (leaves, peels and tubers). The concentration of chromium (Cr) present in leaves ranged from $4.763 \pm 0.089 \mathrm{mg} / \mathrm{kg}>2.968 \pm 0.102 \mathrm{mg} / \mathrm{kg}>0.038 \pm 0.609 \mathrm{mg} / \mathrm{kg}$ in SY, SX, and SZ respectively, with samples from SY (4.763 $\pm 0.089 \mathrm{mg} / \mathrm{kg})$ having the highest concentration while SZ $(0.038 \pm 0.609 \mathrm{mg} / \mathrm{kg})$ had the least concentration. In tubers, SY $(3.914 \pm 0.061 \mathrm{mg} / \mathrm{kg})$ had the highest concentration followed by SZ $(2.672 \pm 0.098 \mathrm{mg} / \mathrm{kg})$ and SX $(1.693 \pm 0.18 \mathrm{mg} / \mathrm{kg})$. Also, SY, SZ and SX had values of $5.075 \pm 0.063 \mathrm{mg} / \mathrm{kg}, 3.243 \pm 1.013 \mathrm{mg} / \mathrm{kg}$ and $3.182 \pm 0.110 \mathrm{mg} / \mathrm{kg}$ respectively in the peels. Analysis of variance (one way ANOVA) findings among the three communities showed no statistically significant difference ( $p>0.05)$.

The mean values recorded in this research were lower than WHO permissible limits of $30.0 \mathrm{mg} / \mathrm{kg}$ but higher than those reported by Ubwa et al., $2013(0.05$ $\mathrm{mg} / \mathrm{kg})$ Apau et al. (2014), Osakwe et al., $2014(0.40 \pm 0.13 \mathrm{mg} / \mathrm{kg})$ Osakwe et al. (2014), Dioborfori-Orji and Edori 2015 (0.14 $0.01 \mathrm{mg} / \mathrm{kg})$ Dibofori-Orji \& Edori (2015), Makanjuola 2016 (0.08mg/kg and 0.11mg/kg) Makanjuola (2006), and Ogbolu, Nwachukwu et al. (2019) (0.04-0.09mg/kg) Ogbolu et al. (2019) and lower than the work of Asaah et al. (2006) (60.6 mg/kg) Asaah et al. (2006), Oguntimehin and Ipinmoroti 2007 (30 mg/kg- 45mg/kg) Oguntimehin and Ipinmoroti (2007). High level of chromium in industrial effluents has been reported by Rawat et al. (2003). Chromium is commonly found at contaminated sites in form of chromium (VI) and it is the dominant form of chromium in shallow aquifers where aerobic conditions exist Wuana and Okieimen (2011).

Chromium plays a vital role in the metabolism of cholesterol, fat, and glucose. Its deficiency causes hyperglycemia, elevated body fat, and decreased sperm count, while at high concentration it is toxic and carcinogenic Chishti et al. (2011). Chromium is associated with allergic dermatitis in humans Scragg (2006) . Epidemiological studies have shown that some chromium components have carcinogenic effects Moore and Ramamoorthy (1984). 


\section{CONCLUSION AND RECOMMENDATIONS}

\subsection{CONCLUSION}

This study revealed the various concentrations of some metals: $\mathrm{Pb}, \mathrm{Cd} \mathrm{As,} \mathrm{Ni}$, and $\mathrm{Cr}$ in cassava leaves, peels and tubers collected from different farmlands along major highways in Rivers State, Nigeria. It was seen from the results obtained that the cassava leaves; peels and tubers from the three different farmlands had different levels of heavy metals as a result of the smokes from automobiles.

Comparative analysis reveals different level of heavy metals from the three communities and samples from Nonwa community (SY) had the highest level of heavy metal in its cassava peel. This may be due to the excessive influx of automobiles that moves towards the Ogoni axis.

Finally, this study revealed that arsenic and cadmium were not detected in cassava tubers samples from SY community and that the major pollutant for cassava leaves, peels and tubers were $\mathrm{Pb}, \mathrm{Ni}$ and $\mathrm{Cr}$. The concentrations of these heavy metals were not statistically significant, except for $\mathrm{Ni}$. There is need to monitor more closely the environment under study, to ensure that appropriate distance is given before cassava is cultivated in order to reduce the availability of these heavy metals in consumable crops consumed by inhabitants of these communities thereby preserving the health of these inhabitants.

\subsection{RECOMMENDATION}

The influence of motor vehicle emission on cassava planted along major highways was evaluated by comparing the level of heavy metal on cassava leaves, peels and tubers from farmlands in three communities in River's state. There were substantially higher levels of $\mathrm{Pb}, \mathrm{Ni}$ and $\mathrm{Cr}$ in the cassava samples (leaves, peels and tubers). It is therefore recommended that agricultural farms should not be situated close to highways to prevent excessive build-up of heavy metals in the food chain.

\section{REFERENCES}

Abah, J., Ubwa, S. T., Audu, S. I. \& Malu, S. P. 2013 Assessment of the levels of some trace metals in soils and roots of cassava grown under usage of agrochemicals in some parts of Benue State, Nigeria. Research Journal of Chemical Science; 3(5), 63- 70. Retrieved from http://www.isca.me/rjcs/Archives/v3/i5/10.ISCA-RJCS-2013-051.pdf

Ajiwe, V. I. E., Chukwujindu, K. C. \& Chukwujindu, C. N. 2018 Heavy Metals Concentration in Cassava Tubers and Leaves from a Galena Mining Area in Ishiagu, Ivo L.G.A of Ebonyi State Nigeria. IOSR Journal of Applied Chemistry; 11(3), 54-58. DOI : 10.9790/5736-1103015458

Akaniwor, J.O., Onyeke, E.N. \& Ifemeje, J.C. 2005 Trace metal levels in raw and heat processed Nigerian staple foods from oil producing areas of Rivers and Bayelsa States. Journal of Applied Sciences and Environmental Management, 2005; 10(2), 23-27. DOI : 10.4314/jasem. V10i2.43653

Amoah, F. M. 2008 "Public Sector Policy on Sustainable Cocoa Economy". Cocoa Research Institute of Ghana. Ghana Public Sector Policy. 2008. Retrieved 


\section{from}

https://static1.squarespace.com/static/537e8bcbe4b09ac6c31f0ae6/t/53 da7b72e4b0ba1f9a9f1140/1406827378536/Africa_Ghana+Cocoa+Public+ Sector+Policy.pdf

Ano, A.O ., Odeoma, S. A. \& Ekwueme, P.0. 2007 Lead and cadmium levels on soils and cassava (Manihot esculenta grantz) along Enugu - Port Harcourt express way in Nigeria. Electronic Journal of Environmental Agricultural and Food Chemistry, 2007; 5, 2024-2031.

Anyakora, C., Nwaeze, K., Awodele, O., Nwadike, C., Arbabi, M. \& Coker, H. 2011 Concentration of heavy metals in some pharmaceutical effluents in Lagos, Nigeria. Journal of Environmental Chemistry Ecotoxicol., 2011; 32. Retrieved from https://doi.org/10.5897/JECE.9000014

Apau, J., Acheampong, A., Appiah, J. A. \& Ansong, E. 2014 Levels and health risk assessment of heavy metals in tubers from markets in the Kumasi metropolis, Ghana. International Journal of Science and Technology, 2014; $3(9), 534-539$.

Asaah, V.A., Abimbola, A.F. \& Suh, C.E. 2006 Heavy metal concentrations and distribution in surface soils of the Bassa industrial zone 1, Doula, Cameroon. The Arabian Journal of Science and Engineering, 2006 ; 31(2A), 147-158.

Biney, C., Amazu, A.T., Calamari, D., Kaba, N., Mbome, I.L., Naeve, H., Ochumba, P.B.O., Osibanjo, O., Radegonde, V., \& Saad, M.A.H. 1994 Review of heavy metals in the African aquatic environment. Ecotoxicology and Environmental Safety, $1994 \quad ; \quad 31, \quad 134-159 . \quad$ Retrieved from https://doi.org/10.1006/eesa.1994.1041

Chishti, K. A., Khan, F. A. \& Hassan , S. S. M. 2011 "Estimation of heavy metals in the seeds of blue and white capitulum's of silybummarianum grown in various districts of Pakistan," Journal of Basic and Applied Science, 2011; 7(1), 4549.

Col, M., Col, C., Soran, A, Sayli., B.S.\& Ozturk, S. 1999 Arsenic-related Bowen's Disease. Palmar Keratosis and Skin Cancer. Environmental Health Prospect., 1999; 107, 687-689. Retrieved from https://doi.org/10.1289/ehp.1071566498

Dibofori-Orji, A. N. \& Edori, O.S. 2015 Analysis of some heavy metals (Pb, Cd, Cr, Fe, $\mathrm{Zn}$ ) in processed cassava flour (garri) sold along the road side of a busy highway. Archives of Applied Science Research, 2015; 7, 15-19. Retrieved from https://www.researchgate.net/profile/0Edori/publication/280921246_Analysis_of_some_heavy_metals_Pb_Cd_Cr_ Fe_Zn_in_processed_cassava_flour_garri_sold_along_the_road_side_of_a_bus y_highway/links/56718f1e08ae90f7843f3341/Analysis-of-some-heavymetals-Pb-Cd-Cr-Fe-Zn-in-processed-cassava-flour-garri-sold-along-theroad-side-of-a-busy-highway.pdf

Ekpete, O.A. \& Festus, C. 2013 Heavy metal distribution in soil along Iwofe Rumuolumeni road. The experiment, 2013; 8(1), 450-455.

Essumang DK. 2015 Some implication of environmental pesticides pollution on malaria control in Ghana. Integrative Pharmacology, Toxicology and Genotoxicology, 2015; 1(1), 11.

Ezeh, H.N. \& Chukwu, E. 2011 Small Scale mining and heavy metals pollution of agricultural soils: The case of Ishiagu mining district, south eastern Nigeria, 
Journal of Geology and Mining Research, 2011; 3(4), 87-104. Retrieved from https://doi.org/10.5897/JGMR.9000069

Galadima, A \& Garba, Z.N. 2012 Heavy metals pollution in Nigeria and consequences. Elizir pollution, 2012; 45(7a), 17-7922.

Harmanescu, M., Alda, L. M., Bordean, D. M., Gogoasa, I. \& Gergen, I. 2011 Heavy metals health risk assessment for population via consumption of vegetables grown in old mining area; a case study: Banat County, Romania. Chemical Central Journal, 2011., 5, 64. Retrieved from https://doi.org/10.1186/1752-153X-5-64

Idakwoji, 2016 Precious. Assessment of heavy metal contamination of soil and cassava plants within the vicinity of a cement factory in north central, Nigeria. Advances in Applied Science Research, 2016; 7, 20-27.

Idris G.N., Asuen G.O., \& Ogundele O.J. 2014 Environmental Impact on Surface and Ground Water Pollution from Mining Activities in Ikpeshi, Edo State, Nigeria International Journal of Geosciences, 2014; 5 (7), 749-755. DOI :10.4236/ijg.2014.57067

Makanjuola, O.M. 2006 Evaluation of Heavy Metals in Cassava Tubers Grown around Two Major Cement Factories in Ogun State, Nigeria International Journal of Research Studies in Biosciences, 2006; 4(11), 26-29. Retrieved from http://eprints.federalpolyilaro.edu.ng/id/eprint/1048

Mathews-Amune, O.C. \& Kakulu, S. 2012 Academic Journal of Environmental Science, 2012; 1(2), 31-35.

Mbong, E. O., Akpan, E. E. \& Osu, S.R. 2014 “Soil-Plant Heavy Metal Relations and Transfer Factor Index of Habitats Densely Distributed with Citrus Reticulated (tangerine)". Journal of Research in Environmental Science and Toxicology, 2014., 3 (4), 61-65 Retrieved from https://doi.org/10.14303/jrest.2014.014

Moore, J.W. \& Ramamoorthy, S. 1984 Heavy metals in natural waters. Applied Monitoring and Impact. $1984 . \quad$ Retrieved from https://doi.org/10.1007/978-1-4612-5210-8

Nabulo, G., Oryem, H., Origa., Nasinyama, G. W. \& D. Cole, D. 2006 Heavy metals in soil. International Journal of Environmental Science \& Technology, 2006; 5, 65-74. Retrieved from https://doi.org/10.1007/BF03325998

Nkwocha, E.E, Pat-Mbano, E.C. \& Tony-Njoku, N. F. 2011 Assessment of Heavy Metal Concentration in Food Crops Grown Around Etelebou Oil Flow Station in Bayelsa State, Nigeria, International Journal of Science and Nature, 2011; 2(3), 665- 670.

Nussey, G. 1998 Metal ecotoxicology of the upper Ohfants River at selected localities and the effect of copper and Zinc on fish blood physiology. Ph.D Thesis, Rand Afrikaans University, South Africa. 1998.

Nwachukwu, M. A., Feng, H. \& Alinnor, J. 2013 Trace metal Deposition in soil from Auto-mechanic village to urban residential areas in Owerri, Nigeria. Journal of Environmental. Science, 2013); 4, 310-322. Retrieved from https://doi.org/10.1016/j.proenv.2011.03.036

Ogabiela, E. E., Udiba, U. U., Adesina, O. B., Hammuel, C., Ade-Ajayi, F. A., Yebpella, G. G., Mmereole, U. J. \& Abdulahi, M. 2011 Assessment of Metal levels in Fresh 
Milk from Cows Grazed around Challawa Industrial Estate of Kano, Nigeria. Journal of Basic Applied Science, 2011; 1 (7), 533-538.

Ogbolu, Nwachukwu, S., Izomor, R., Oghonyon, E., Nworu, \& Jerome, S. 2019 Heavy Metal Concentrations in Yam and Cassava Tubers from Enyigba Lead-Zinc Mining Site in South Eastern Nigeria. IOSR Journal of Applied Chemistry, $2019 ; 11,39-43$.

Ogbolu, Nwachukwu, S., Izomor, R., Oghonyon, E., Nworu, \& Jerome, S. 2019 Heavy Metal Concentrations in Yam and Cassava Tubers from Enyigba Lead-Zinc Mining Site in South Eastern Nigeria. IOSR Journal of Applied Chemistry, 2019; 11, 39-43.

Ogundiran, M. B. \& Osibanjo, 0. 2009 Mobility and speciation of heavy metals in soils impacted by hazardous waste. Chemical Speciation and Bioavailability, 2009; 21(2), 59-69. Retrieved from https://doi.org/10.3184/095422909X449481

Oguntimehin, I. \& Ipinmoroti, K. 2007 Profile of heavy metals from automobile workshops in Akure, Nigeria Journal of Environmental Science and Technology, 2007; 1-8. Retrieved from https://doi.org/10.3923/jest.2008.19.26

Okoronkwo, N. E., Ano, A. O. \& Onwuchekwa, E. C. 2005 Environment, Health and Risk Assessment: A Case Stud of the Use of an Abandoned Municipal Waste Dump Site for Agricultural Purposes. African Journal of Biotechnology, 2005; 4 (11), 1217- 1221.

Onde, S. S., Dursun, S., Gezgin \& Demibas, A. 2007 Determination of heavy metal pollution in grass and soil of city green area (Konya, Turkey). Polish Journal of Environmental Study, 2007; 16 (1), 145 - 154.

Onyedika, G.O \& Nwosu, G.U. 2008 Lead, zinc and cadmium in root crops from mineralized galena-sphalerite mining areas and environment, Pakistan Journal of Nutrition, 2008; 7(3), 418-420. Retrieved from https://doi.org/10.3923/pjn.2008.418.420

Osabohien, E., Otutu, O. J. \& Otuya, O. B. 2013 Concentration of Heavy Metals in Soils, Tubers and Leaves of Cassava Plants Grown around some Oil Spill and Gas Flaring Zones in Delta State, Nigeria. Applied Science Journal, 2013; 1(1), 1 -6 .

Osakwe, S., Vincent.,Akpoveta, \& Osakwe, J. 2014 The Impact of Nigerian Flood Disaster on the Soil Quality of Farmlands in Oshimili South Local Government Area of Delta State, Nigeria. Chemistry and material research, 2014; 6, 68-77.

Osakwe, S.A. 2009 Heavy metal distribution and bioavailability in soils and cassava along Warri - Abraka expressway Delta state Nigeria. Journal of Chemical Society of Nigeria, 2009; 34 (1), 211-217.

Oti, W, J. O. \& Nwabue, F. I. 2013 Heavy Metals Effect due to Contamination of Vegetables from Enyigba Lead Mine in Ebonyi State, Nigeria. Environment and Pollution, 2013; 2, 1 Retrieved from https://doi.org/10.5539/ep.v2n1p19

Pam, A. A., Sha'Ato, R. \& Offem, J.O. 2013 Contributions of Automobile Mechanic Sites to Heavy Metals in Soil: A Case Study of North Bank Mechanic Village Makurdi, Benue State, Central Nigeria. Journal of Chemical, Biological and Physical Science, 2013; 3(3), 2337-2347. 
Park, J. H., Lamb, D., Paneerselvam, P., Choppala, G. \& Bolan N. 2011 Role of organic amendments on enhanced bioremediation of heavy metal (loid) contaminated soils. J Hazard Mater, 2011; 185, 549-574. Retrieved from https://doi.org/10.1016/j.jhazmat.2010.09.082

Qui, X. X., Huang, D. F., Cai, S. X., Chen, F., Ren Z. G. \& Cai, Y. C. 2000 Investigation on Vegetables pollution and pollution sources and its control in Fuzhou, Fujian Province. Fujian Journal of Agricultural Science, 2000; 15, 16-21.

Rawat, M., Moturi, M.C.Z. \& Subramanian, V. 2003 Inventory compilation and distribution of heavy metals in waste water from small-scale industrial areas of Delhi. 2003. Retrieved from https://doi.org/10.1039/b306628b

Rehman, A. H., Ullah, R. U., Khan, \& Ahmad, I. 2013 "Population based study of heavy metals in medicinal plant Capparis decidua," International Journal of Pharmacy and Pharmaceutical Sciences, 2013; 5(1), 108-113. Retrieved from https://doi.org/10.1155/2013/621265

Scragg, A. 2006 Environmental Biotechnology, Oxford University Press, Oxford, U.K. 2006.

Sparg, S. G., Light, M. E. \& Van Staden, J. 2004 Biological activities and distribution of plant saponins. Journal of Ethnopharmacology, 2004; 94, 219. Retrieved from https://doi.org/10.1016/j.jep.2004.05.016

Ubwa, S.T., Atoo, G.H., Offem, J.O., Abah, J. \& Asemave, K. 2013 Effect of Activities at Gboko Abattoir on some Physical Properties and Heavy Metals levels of surrounding soil. International Journal of Chemistry, 2013; 5(1) 49-57. Retrieved from https://doi.org/10.5539/ijc.v5n1p49

Udiba, U. U., Akpan, E. R. \& Antai, E. E. 2019 Soil lead concentration in Dareta village, Zamfara, Nigeria. Journal of Health Pollution, 2019; 9(23), 1-15. Retrieved from https://doi.org/10.5696/2156-9614-9.23.190910

WHO (World Health Organisation). 1996 Permissible limits of heavy metals in soil and plants (Geneva, World Health Organization) Switzerland. 1996.

Wang, Y., Wang, H. \& Shee, D. 2007 Measuring e-learning systems success in an organizational context: Scale development and validation. Computers in Human Behavior, 2007; 23(4), 1792-1808. Retrieved from https://doi.org/10.1016/j.chb.2005.10.006

Wepener, V., Van V., Johan \& Preez, H. 2001 Uptake and distribution of a copper, iron and zinc mixture in gill, liver and plasma of a freshwater teleost, Tilapia sparrmanii. 2001.

Wuana, R.A. \& Okieimen, F.E. 2011 Heavy Metals in Contaminated Soils: A Review of Sources Chemistry risks and Best Available Strategies for Remediation. Scholarly Research Network, 2011; 1-20. Retrieved from https://doi.org/10.5402/2011/402647 